\title{
Social Discrimination as a Predictor of Criminal Recidivism: A Study of Ex-Prisoners in Metropolitan Kano-Nigeria
}

\author{
Aminu Musa Ahmed, Abd Halim B. Ahmad \\ College of Law, Government and International Studies, Universiti Utara Malaysia \\ aminmusaahmed@gmail.com
}

\begin{abstract}
Social discrimination is one of the major challenges faced by the ex-prisoners when returning to their society which could have an adverse effect on criminal recidivism. The objective of this study is to examine the effects of social discrimination on criminal recidivism among ex-prisoners in metropolitan Kano using two dimensions (racial and criminal record discrimination). Data was collected using survey questionnaire and it was analysed using Partial Least Squares model (PLS). The finding of the study shows that both racial discrimination and criminal record discrimination of ex-prisoners are having significant effects towards criminal recidivism and they accounted for $42.5 \% R^{2}$. Moreover, criminal record discrimination was found to have larger effect than racial discrimination. It is concluded that, social discrimination of ex-prisoners is a predictor of criminal recidivism and criminal record type of discrimination is having more effect toward recidivism.
\end{abstract}

Keywords: Discrimination, ex-prisoner, recidivism, crime, predictors

\section{Introduction}

Ex- prisoner faces many constrains and challenges upon their return to their societies from the prison. Securing good and enough accommodations, family interrelationship, control in substance and drug abuse as well as mental health issues are some of the key and crucial issues that play a leading role in the successful reentry and reintegration of the former inmates. However, the greater part of the challenges faced by the exprisoners is the intentional social discrimination shown to them from different angles of the society. For instance, discrimination in terms of employment opportunities, accommodation, and education among others. These factors have negative effects towards successful re-entry after their imprisonment (Holzer, Raphael \& Stoll, 2002a; Waldfogel, 1994). This is largely because those who are discriminated for instance in terms of employment are significantly and more likely to return to their criminal activities than those who are employed (Burton, Cullen \& Travis, 1987; Clear, 2007; Freeman, 1994). Social discrimination of former inmates negates the chances of integrating people into their societies; it disorganizes their lives, and reduces their social capital. The issue of social discrimination among the ex-prisoners which is critical aspect of the returning prisoners, and it is considered as another collateral effect of imprisonment couple with the effects of stigma which further compounded and aggravated the issue of discrimination in terms of educational, accommodation and securing employment (Albright \& Denq, 1996; Giguere \& Dundes, 2002; Hirschfield \& Piquero, 2010; Pager, 2007; Uggen, 2000; Uggen, Vuolo, Lageson, Ruhland \& Whitham, 2014).

Moreover, the stigma and discrimination that is connected with previous criminal record is usually invoked as one of the major pathway that link imprisonment as completely negative, which also affects the level of enduring mental health among the ex-prisoners. As such researchers on ex-offenders highlight their experiences with stigma and discrimination (Braman, 2004; Clemmer, 1940; Goffman, 1961; Haney, 2003; Sykes, 1958/2007). Imprisonment is considered as a life event and a defining moment especially for the exprisoners which results into continues stigmatization of the ex-prisoners thereby creating long time discrimination and the denial of many opportunities to the ex-prisoners after their release. It is highlighted however, that, even years after release, discrimination base on prison status still holds in multiple social settings (Braman, 2004) and the stigma always determines the discrimination that former inmates experience in the labour market(Pager, 2003), voting rights (Uggen \& Manza, 2002), and family life (Massoglia, Remster \& King, 2011). The magnitude of such discrimination plays a crucial role in determining the level to which the ex-prisoners conform or continued with their previous criminal behaviour (recidivism). 
The purpose of this study is to determine the role of social discrimination of ex-prisoners as a predictor of criminal recidivism among ex-prisoners in Kano-Nigeria using two dimensions of discrimination (racial and criminal records).

\section{Literature Review}

Social Discrimination of Ex-prisoners: Prisoners when returning to their various societies do not experience equality in terms of reception and treatment which creates numerous dilemmas towards re-entry. Majority of the returning inmates encounter difficulties especially due to the discrimination in many areas that they need to have adjustment: employment opportunities, access to government services and benefits, stable accommodation, treatment programs, family support, access to health care, for successful re-entry (Naser \& LaVigne, 2006, Travis \& Petersilia, 2001). According to Beck \& Shipley (1989) the loss of human capital creates additional challenges for re-entering prisoners into their communities. That is, the depreciation of human capital as a result of imprisonment diminishes the possible prospects for success in many areas, which is further compounded by social discrimination especially when ex-offenders are trying to find employment and where the employment is found, it is usually an unskilled one with a disparity in pay as against those with no criminal records (Kling, 2006).This is why Western, Kling, and Weiman (2001) concluded that the experience of discrimination in securing an employment do reduces the chances of economic success of the ex-prisoner.

Moreover, it can be argued that, ex-prisoners are discriminated and are having lower earning capacities and rates of employment when compared to other groups (Freeman, 1992; Grogger, 1995; Lyons \& Pettit, 2011; Western, Kling, \& Weiman, 2001). Also it has been reported that people do discriminate against and would not hire people with criminal backgrounds (Harding, 2003). In a study of formerly incarcerated persons' perception of stigma and possible discrimination, majority of the respondents revealed that, they usually avoid disclosing their criminal histories when it comes to job applications so as to avoid rejection based on their ex-inmate status (LeBel, 2012). Though the strategy proved to be effective but only in a situation where the job is on short term basis or when it does not require much background checks (Harding, 2003). However, the full scale discrimination comes up when the job require mandatory background checks, hence it would certainly become out of their reach, because ex-prisoners are usually unable to conceal their prison status.

On the other hand, the issue of family support system also has been considered to be important factor for successful re-entry of the ex-prisoners (Kushel et al., 2005; La Vigne, Visher \& Castro, 2004). Though, the exprisoners faces many discriminations while returning home, however, it is pertinent to note that provision of shelter when an inmate is released from prison can greatly reduces many financial pressures, and family members also can secure job opportunities for returning ex-prisoners through the network of friends, employers, and in some instances religious institutions (Visher, Debus-Sherrill \& Yahner, 2008). While for those under parole and find employment shortly after their release usually does so through connections of friends and family members with whom they maintained contact during their incarceration (Cobbina, 2009; MallikKane \& Visher, 2008; Nelson, Dees \& Allen, 1999; Visher \& Kachnowski, 2007). Without the help of family and friends, returning ex-inmates are likely to face much more discrimination and spend longer time before securing an employment, if they would find it at all (Nelson et al., 1999).Alternatively, parolees who were employed before their incarceration may be able to re-establish contact with such employers prior to release, and this will improve their chances of finding employment (Visher et al., 2008).

However, it is evident that, majority of the ex-prisoners do not have decent and legitimate employment records, as such only few of them are likely to have advantage of such previous relationships. Thus, one of the best ways for ex-prisoners to find work is through family, community, and former employment contacts. Many ex-inmates are leaving prison without such provisions in the sense that many of their contacts in the community may be criminally inclined and are not in the position to offer some leads in terms of legitimate employment (Hagan, 1993). Equally, their stigmatized backgrounds, deficiencies in education, inappropriate skills, and their lack of pro-social contacts coupled with intentional discrimination (Ostermann, 2011) from the community due to their prison status can affect many ex-prisoners' ability to secure work, which can inhibit both their current and future economic status (Pager, 2003; Western, 2006; Western et al., 2001). 
Criminal Record and Racial Discrimination: According to Frank et al. (2014) discrimination on the basis on individual's criminal record may serve as an added obstruction. This is even in the areas of healthcare delivery among the ex-prisoners (Schnittker \& John, 2007; Smedley et al., 2003). Criminal record of exprisoners has been recognized as a stigmatized social status that can produce an unfair treatment and daily indignities across a range of societal social settings (Schnittker \& John 2007; Uggen \& Manza, 2002). Discrimination based on criminal record has been strongly established in the areas of employment, accommodation and other social services not only through self-report from former inmates, but also through the use of many audit studies and other novel experimental designs (Pager \& Shepherd, 2008; Pager et al., 2009; Uggen et al., 2004). This is evident and applicable in terms of discrimination even in the areas of healthcare provision for the ex-prisoners. This situation can also give the ex-prisoners a chance to continue with their previous criminal behaviours.

$\mathbf{H}^{1}$ There is significant relationship between discrimination of ex-prisoners base on criminal record and criminal recidivism.

Turney et al. (2013) argued that, the perceived discrimination based on race or racial background has been found to be the most generally and extensively studied form of social discrimination especially in the United States. This has been cited as an imperative factor in explaining racial discrimination and disparities in multiple areas (Williams, 1999; Williams \& Mohammed, 2009). Nevertheless, in spite of the high rates of incarceration (Bannon et al., 2010) and recidivism, especially among the minority men, the effect of criminalrecord based discrimination, is considered as more or less a distinct type of discrimination (Frank et al., 2014; Pager et al., 2009). However, given the important consequences of racial discrimination, the minority men who have been disproportionately affected by the rise in massive incarceration into the prison may become more vulnerable population. They may experience social discrimination from both their criminal record as well as racial one. Incarceration as such, stands to be unique issue because the racial and social class disproportionality in incarceration rates provides evidence of structural forms of discrimination (Krieger, 2012). On the other hand, it has been contended that, incarceration might have help in explaining racial differences which is more broadly distributed risk factors, such as discrimination (Iguchi, Bell, Ramchand \& Fain, 2005; Schnittker \& John, 2007). Thus, it is pertinent to note that both criminal record discrimination and racial discrimination function separately but also cumulatively affect the lives of ex-prisoners especially when it comes to the reasons for becoming criminal recidivists (Travis \& Stacey, 2010).

$\mathbf{H}^{2}$ There is a relationship between racial discrimination of ex-prisoners and criminal recidivism.

Therefore, base on above explanation it can be deduce that social discrimination started and can be determined when there is social deprivation (Griswold \& Pearson, 2005). In the first instance and later extended to discrimination and consequently social exclusion. To this extent therefore, it can be said that social exclusion of ex-prisoners starts from the inception of depriving them (Richards \& Jones, 2004) some basic needs of human survival deliberately simply because of their social status or their prison attributes. This is not same to other category of people, so much so that, they would be intentionally discriminated and by implication socially excluded.

Criminal Recidivism: Re- integration of released ex- prisoners who are back into the community poses an important challenges to almost all countries globally (Travis et al., 2001; Farrall and Sparks, 2006; Wartna and Nijssen, 2006). Thus, this process is considered to be critical due to so many reasons: the preservation of public safety and community vitality, controlling the expensive rate of extension of the activities of criminal justice systems and reducing the wide range of collateral costs that may arise in the event of large parts of exprisoners are not brought back to the prison institution. Many researches that focused on criminal recidivism concentrated and analysed the concept of criminal recidivism from the point of reconviction and reimprisonment among ex-prisoners as the basis for understanding the phenomenon. That is, majority of the inmates who are imprisoned and later released are most likely to be reconvicted or to be re-imprisoned (Gendreau \& Ross, 1979; Beck \& Shipley, 1989; Broadhurst \& Maller, 1990; Lloyd et al., 1994; Bonta et al., 1996; Gendreau et al., 1996; Kershaw et al., 1999; Langan and Levin, 2002; Cunliffe and Shepherd, 2007).

According to Maltz (2001) recidivism within the context of criminal justice system can be conceptualised as the reversion of an individual offender into the previous criminal behavior after he/ she has been convicted of a prior offense after the individual has been processed, sentenced, and thereby presumed to be corrected. 
Moreover, it happens as a result of individual's failure to live up to society's expectations. It is a tendency of fall back into previous criminal behavior and portrays re-arrest, re-conviction, and re-incarceration of exprisoner for the second or more times and it cannot usually occur where relapse did not occur within a specific period. It also varies greatly from place to place depending on the amount and quality of intervention, surveillance and enforcement (Schmallenger \& Smykla 2005).

\section{Figure1: Research Model}

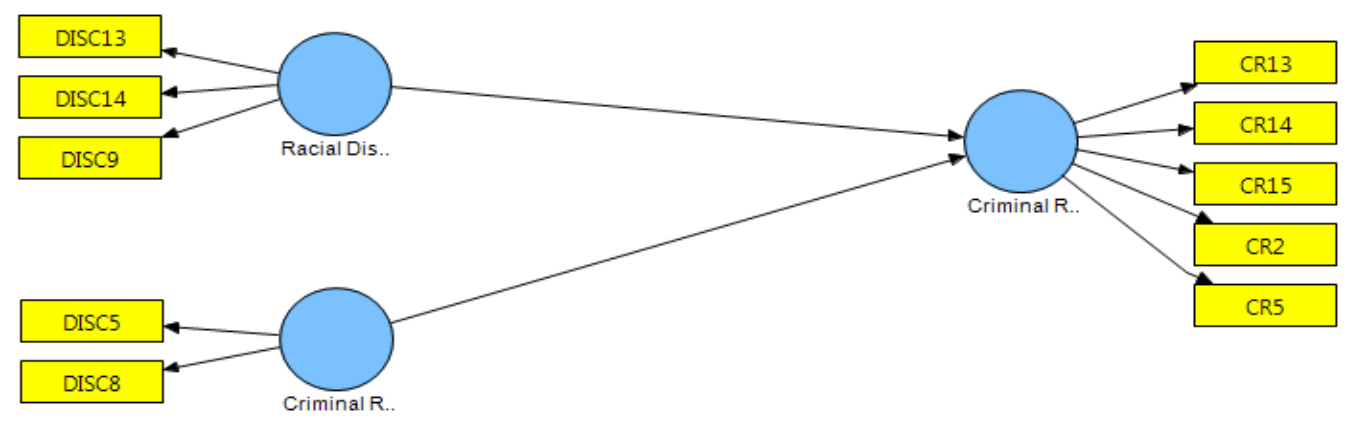

\section{Methodology}

Sample and Data Collection: The population of this study are the ex-prisoners in Kano metropolis. Four hundred and four (404) questionnaires were distributed initially and 256 (63.4\%) were found to be fit for analysis as suggested 30\%, and $5-10$ times the number of study variables (Hair, Andersen, \& Tatham, 2010; Pallant, 2001) of the data sample is adequate for analysis. The respondents were selected using purposive sampling strategy. The data was obtained using questionnaire instrument. Responses were categorized by using five point "Likert" scale (1Strongly Disagree and 5 strongly Agree). The model of this study was empirically used and tested using Structural Equation Modelling (PLS-SEM) path modelling (Hair, Ringle \& Sarstedt, 2011) in analysing the data taking into account both measurement and structural model as suggested by Hair et al. (2010).

\section{Measurement}

Racial Discrimination: Racial discrimination is perceived and used as discrimination that the ex-prisoners do face in their community base on racial or ethnic point of view. According to Turney et al., (2013) the perceived discrimination based on race or racial background has been found to be the most generally common among ex-prisoners and is also considered as imperative factor in explaining racial discrimination and disparities in multiple areas (Williams, 1999; Williams \& Mohammed, 2009). It is basically base on ethnic or racial disparities by virtue of being an ex-prisoner.

Criminal Record Discrimination: Discrimination base on criminal record of ex-prisoners is very common and it has been recognized as part of the stigmatized social status that can produce an unfair treatment and daily indignities across a range of societal social settings (Schnittker \& John 2007; Uggen \& Manza 2002). Discrimination based on criminal record has been strongly established in many areas: employment, shelter, education, family, neighbours, peers, healthcare and other social services (Pager \& Shepherd 2008; Pager et al., 2009; Uggen et al., 2004). It is basically due to the individual prior criminal records and other criminal activities with less emphasis on his/her racial or ethnic inclination. For both the two constructs eighteen items measurement used by Turney et al. (2013) were adapted and used though only five were found to have the required loadings in PLS.

Criminal Recidivism: Like many other studies on criminal recidivism, the main focus and measurement of criminal recidivism centred on the re-conviction and re-imprisonment of an ex-offender after he/she must have undergone the process of criminal punishment especially prison institution. That is, majority of the former inmates who are imprisoned for one crime or the other and later released are more likely to be re- 
convicted or re-imprisoned (Gendreau and Ross, 1979; Beck and Shipley, 1989; Broadhurst and Maller, 1990; Lloyd et al., 1994; Bonta et al., 1996; Gendreau et al., 1996; Kershaw et al., 1999; Langan \& Levin, 2002; Cunliffe \& Shepherd, 2007) again due to their re-engagement into criminal activities. The measurements used by Stahler et al. (2013), Meade et al. (2012), Listwan et al. (2010) and Harris et al. (2009) were adapted and used.

\section{Results and Discussion}

Demographic profile of respondents: Majority of the respondents $86.7 \%$ are males and $13.3 \%$ are females. Those that are single are $85.2 \%$, married $9.4 \%$, divorced $3.9 \%$ and separated $1.6 \%$. Majority $42.5 \%$ are between $25-29$ years with only $7.0 \%$ who are 40 and above years. Educationally, majority $52.7 \%$ are with no formal education, $16.4 \%$ with primary, $25.4 \%$ have secondary and $5.5 \%$ are having post secondary education. Also, overwhelming majority of the respondents $94.5 \%$ and $88.3 \%$ are Muslims and Hausa/Fulani. Also, majority $68.0 \%$ are not employed.

Goodness of Measures: In this study attempts was made to determine the construct validity, in which twostep modelling approach was used in line. The assessment of the convergent validity and reliability was determine first which was followed by the assessment of discriminant validity and internal consistency reliability as shown in Tables 1 and 2, respectively. This is in line with the rule of thumb, that a construct validity is ascertained when the loadings of the indicators are higher than 0.7, Composite Reliability is greater than 0.7, Average Variance Extracted is greater than 0.5 (Bagozzi et al., 1991; Fornell \& Larcker, 1981; Gefen et al., 2000; Hair et al., 1998; Nunnally \& Bernstein, 1994).

\section{Figure 2: Algorism of Structural Model}

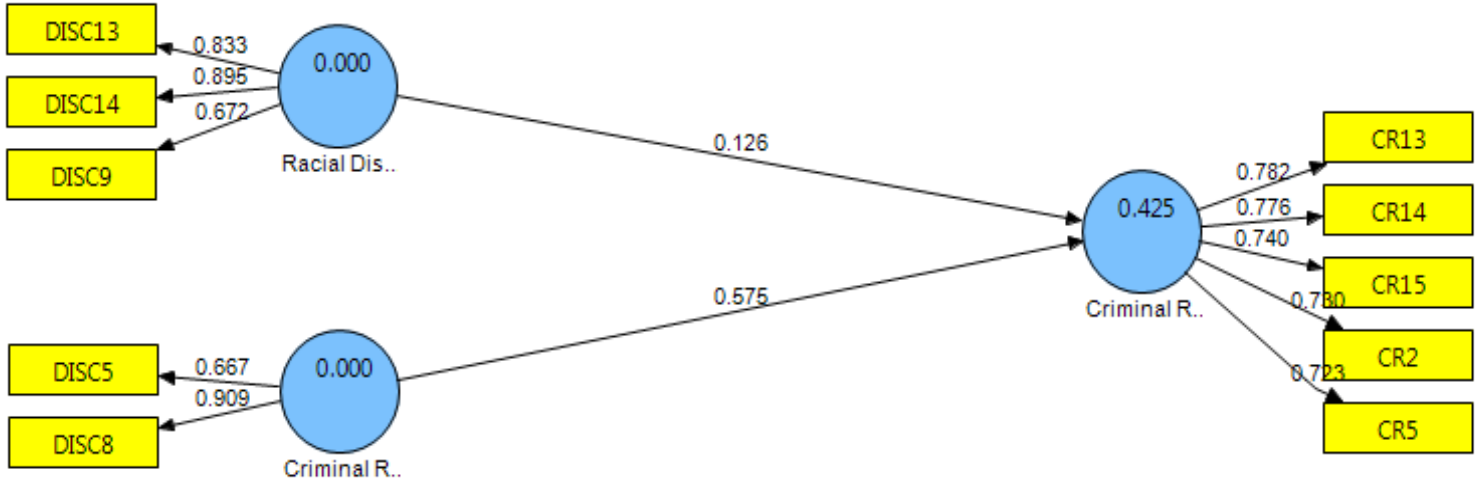

Table 1: Items Loadings, Average Variance Extracted and Composite Reliability

\begin{tabular}{llll}
\hline Latent Variables and Items & Loadings & AVE & CR \\
\hline Criminal Recidivism & & 0.56 & 0.87 \\
CR14 & 0.78 & & \\
CR15 & 0.74 & & \\
CR2 & 0.73 & & \\
CR5 & 0.72 & \\
CR13 & 0.78 & 0.77 \\
Criminal Record & & & \\
DISC5 & 0.67 & 0.64 & \\
DISC8 & 0.91 & & \\
Racial Discrimination & & & \\
DISC13 & 0.83 & 0.65 \\
DISC14 & 0.90 & & \\
DISC9 & 0.67 & & \\
\hline
\end{tabular}


For the assessment of the reliability analysis, the paper established discriminant validity by calculating the shared variance between each of the three constructs there by establishing that it was less than the average variance extracted from each individual construct (Bagozzi \& Lynn, 1982; Fornell \& Larcker, 1981). As indicated in Table 2, the squared correlation for each construct is less than the square root of average variance extracted by the indicators that measure a construct, which indicates adequate discriminant validity. Thus, the measurement model was found to have demonstrated an adequate reliability, convergent and discriminant validities.

Table 2: Discriminant Validity

\begin{tabular}{llll}
\hline Latent variables & Criminal Recidivism & Criminal Record & Racial Discrimination \\
\hline Criminal Recidivism & 0.75 & & \\
Criminal Record & 0.64 & 0.80 & \\
Racial Discrimination & 0.44 & 0.54 & 0.81 \\
\hline
\end{tabular}

Figure 3: Bootstrapping of the Structural Model

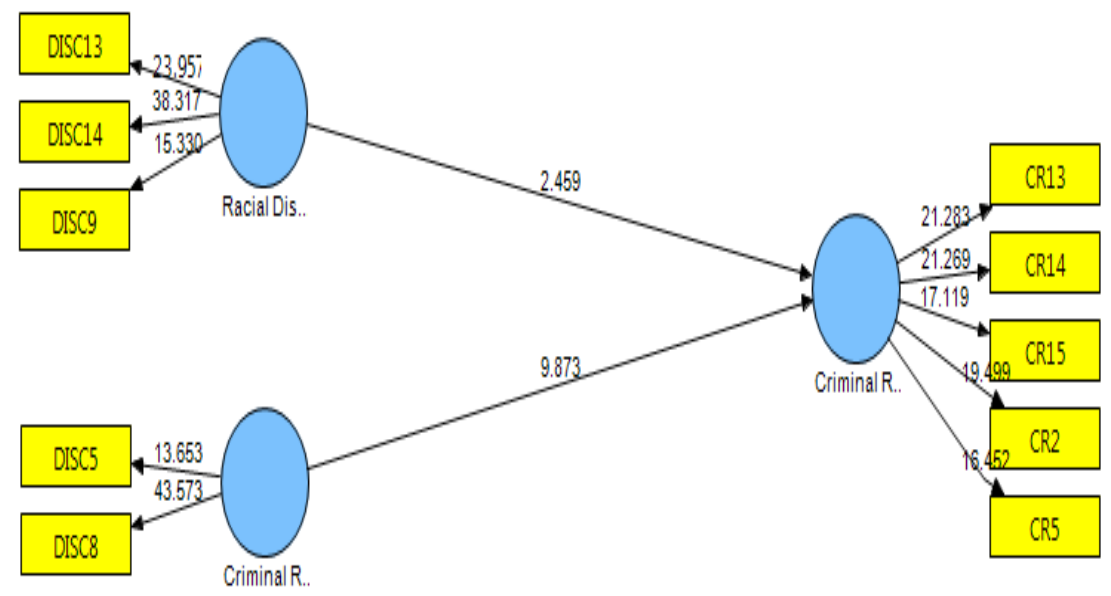

This study examines social discrimination as a predictor of criminal recidivism among the ex-prisoners in metropolitan Kano-Nigeria. However, the study used two main dimension of social discrimination as the yard stick for measuring the overall discrimination (racial and criminal record discrimination). Thus, the interpretation of hypotheses result is presented in Table 3 below. The hypotheses result shows that, there is significant relationship between criminal record discrimination of the ex-prisoners and criminal recidivism. Path coefficient ( $\beta=0.574 ; t=9.872, \mathrm{p}=0.00$ ). This finding is line with Frank et al. (2014) and Schnittker \& John (2007). Thus $\mathbf{H}^{\mathbf{1}}$ is supported. Moreover, racial discrimination of ex-prisoners is also found to have significant relationship with criminal recidivism $(\beta=0.126 ; t=2.459, \mathrm{p}=0.01)$. Hence, $\mathbf{H}^{2}$ is also supported and also in line with Turney et al. (2013).

Table 3: Model Hypotheses

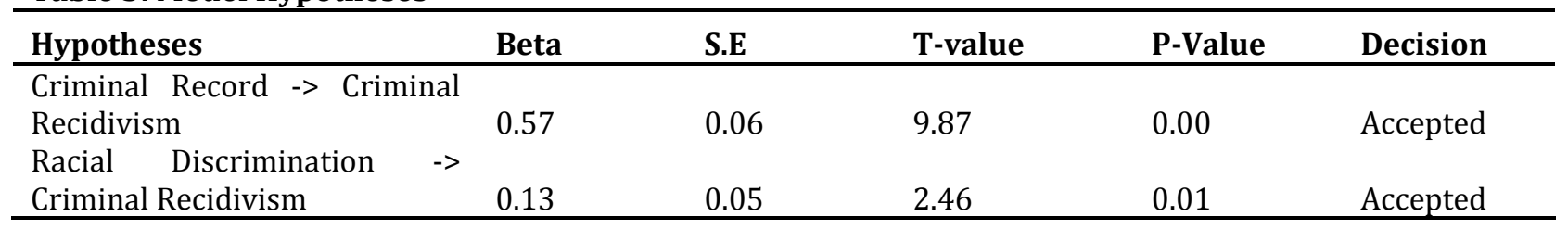

For the effect size of the constructs used in the study, it is revealed that discrimination base on previous criminal record is having more effect on the criminal recidivism among the ex-prisoners in Kano. This is because the effect size shows that criminal record is having 0.4035 and is considered large, while racial discrimination is having 0.0191 which is no effect (Chin, 1998; Cohen, 1988) as shown in Table 4 . Whereas, 
the model is found to have predictive relevance in the sense that it is having 0.2248 this is in line with the suggestion of Geisser (1974) and Stone (1974) who suggested that any model with predictive relevance of more than 0 has a predictive relevance as shown in Table 5.

Table 4: Effect Size $\mathbf{f}^{2}$

\begin{tabular}{llllc}
\hline R-squared & Included & Excluded & f-squared & Effect size \\
\hline Racial Discrimination & 0.43 & 0.41 & 0.02 & None \\
Criminal Record & 0.43 & 0.19 & 0.40 & Large \\
\hline
\end{tabular}

Table 5: Predictive Relevance $\mathbf{Q}^{2}$

\begin{tabular}{llcc}
\hline Total & SSO & SSE & 1-SSE/SSO \\
\hline Criminal Recidivism & 1280 & 992.2889 & 0.2248 \\
\hline
\end{tabular}

\section{Conclusion, Discussion and Theoretical Contribution}

This study examines social discrimination of ex-prisoners as a predictor of criminal recidivism in metropolitan Kano using two dimensions of social discrimination as a yard stick for measuring the discrimination. The study findings show that social discrimination that the ex-prisoners are facing when returning back from prison is found to have significant effects towards criminal recidivism among the exprisoners. However, despite the fact that, all the two dimension of social discrimination are significant, it is worthy to note that racial discrimination is having a relatively lower effect whereas discrimination base on previous criminal records was found to have higher effects for criminal recidivism. This therefore, indicates that, discrimination base on criminal records can have more effect and influences the continuation of the criminal behaviour after incarceration. Also, the findings of this study is in line with other previous studies, racial discrimination (Williams, 1999; Williams \& Mohammed, 2009); Turney et al. (2013) as well as discrimination base on previous criminal records (Schnittker \& John, 2007; Uggen \& Manza, 2002). Equally, the above finding is supported by that of Western (2006) who established that, those ex-prisoners are discriminated in many respects. Their findings revealed what they called 'collateral consequences' of discrimination or bans on former inmates which subsequently leads to reoffending. Moreover, the findings of this study is consistent with the argument of Western (2006) who concluded that, when offender is discriminated for instance in terms of getting employment that can be considered as compelling evidence that exist as a collateral consequences which can prompt increase in reoffending (Holzer et al., 2002a).

Theoretically, this study contributes to the existing body of knowledge about the predictor of criminal recidivism. Specifically, the study established that, discrimination that occurred as a result of the individual criminal record is more prone to criminal recidivism. In other words, though, ex-prisoners do faces some level of discrimination after their release from the custody as established by many studies. But, the discrimination they face which is linked to their previous records is evidently making them to become criminal recidivists. Therefore, it can be deduced that, the paint of discrimination among the ex-prisoners in relation to their re-offending lies on them being discriminated by virtue of their criminal status as exprisoners.

Limitation and Direction for future: Researches all over cannot be concluded without some lingering limitation. This study has some few limitations: one of the limitations of this study is that, it only focus ed on the ex-prisoners alone, that is, only the ex-inmates where targeted and data was sought from them only. Thus, it appeared to be one sided as such other studies should include members of the society as part of the respondents so that balance information could be attained with the regards to social discrimination vis-a-vis criminal recidivism. Another limitation of the study also is that no policy maker has been contacted to get input from their side on the effects and why social discrimination of ex-prisoners is more or less institutionalized. Thus future studies can explore such limitations and build on them. 


\section{References}

Albright, S. \& Denq, F. (1996). Employer attitudes toward hiring ex-offenders. The Prison Journal, 76(2), 118137.

Bagozzi, R. P., Youjae, Y. \& Phillips, L. W. (1991). Assessing construct validity in organizational research. Administrative Science Quarterly, 36, 421-458

Bagozzi, R. P. \& Lynn, P. W. (1982). Representing and testing organizational theories: a holistic construal. Administrative Science Quarterly, 27, 459-489.

Bannon, A., Nagrecha, M. \& Diller, R. (2010). Criminal justice debt: A barrier to re-entry. New York, NY: Brennen Centre for Justice, New York University School of Law. Retrieved fromhttp://www.brennancenter.

Beck, A. J. \& Shipley, B. E. (1989). Recidivism of prisoners released in 1983. Washington, DC: US Department of Justice, Bureau of Justice Statistics

Burton, V. S., Cullen, F. T. \& Travis, L. F. (1987). Collateral consequences of a felony conviction: A national study of state statutes. Federal Probation, 3, 52-60

Bonta, J., Harman, W. G., Hann, R. G. \& Cormier, R. B. (1996). Prediction of Recidivism among Federally Sentenced Offenders: A Re-Validation of the SIR Scale, The. Canadian Journal of Criminology, 38, 61.

Braman, D. (2004). Doing time on the outside: Incarceration and family life in urban America. Ann Arbor: University of Michigan Press.

Broadhurst, R. G. \& Mailer, R. A. (1990). The recidivism of prisoners released for the first time: Reconsidering the effectiveness question. Australian \& New Zealand Journal of Criminology, 23(2), 88-104.

Cobbina, J. (2009). From prison to home: Women's pathways in and out of crime. Retrieved from http://www.ncjrs.gov/pdffiles1/nij/grants/226812.pdf

Cohen, J. (1988). Statistical power analysis for the behavioral sciences (2nd ed.). Hillsdale: Lawrence Erlbaum Associates, NJ.

Cunliffe, J. \& Shepherd, A. (2007). Reoffending of Adults: Results from the 2004 Cohort. Home Office Statistical Bulletin 06 / 07. London: Home Office.

Chin, W. W. (1998). Issues and Opinion on Structural Equation Modeling. Management Information Systems Quarterly, 22(1), 7-15

Clear, T. R. (2007). Imprisoning communities: How mass incarceration makes disadvantaged neighbourhoods worse. New York: Oxford University Press.

Clemmer, D. (1940). The prison community. New York, NY: Holt, Rinehart, \& Winston.

Farrall, S. \& Sparks, R. (2006) Introduction. Criminology and Criminal Justice, 6(1), 7-17

Fornell, C. \& Larcker, D. F. (1981). Evaluating structural equation models with unobservable variables and measurement error. Journal of Marketing Research, 18(1), 39-50. http://dx.doi.org/10.2307/3151312

Frank, J. W., Wang, E. A., Nunez-Smith, M., Lee, H. \& Comfort, M. (2014). Discrimination based on criminal record and healthcare utilization among men recently released from prison: a descriptive study. Health \& Justice, 2(1), 1-8.

Freeman, R. B. (1994). Crime and the job market. NBER Working Paper No. 4910. Cambridge, MA: National Bureau of Economic Research.

Freeman, R. (1992). Crime and unemployment of disadvantaged youths. In G. Peterson \& W. Vroman (Eds.), Urban labor markets and job opportunity. Washington, DC: Urban Institute Press.

Gefen, D., Straub, D. W. \& Boudreau, M. C. (2000). Structural equation modelling and regression: Guidelines for research practice. Communications of the Association for Information Systems, 4(7), 1-70.

Geisser, S. (1974). A predictive approach to the random effect model. Biometrika, 61(1), 101-107

Gendreau, P., Little, T. \& Goggin, C. (1996). A meta-analysis of the predictors of adult offender recidivism: what works! Criminology, 34(4), 575-608.

Gendreau, P. \& Ross, B. (1979). Effective correctional treatment: Bibliotherapy for cynics. Crime \& Delinquency, 25(4), 463-489.

Giguere, R. \& Dundes, L. (2002). Help wanted: A survey of employer concerns about hiring ex-convicts. Criminal Justice Policy Review, 13(4), 396-408.

Goffman, E. (1961). Asylums: Essays on the social situation of mental patients and other inmates. Garden City, NY: Anchor Books. 
Griswold, E. A. \& Pearson, J. (2005). Turning offenders into responsible parents and child support payers. Family Court Review, 43, 358-371. doi:10.1111/j.1744-1617.2005.00039.x

Grogger, J. (1995). The effects of arrests on the employment and earnings of young men. Quarterly Journal of Economics, 110, 51-71. doi: 10.2307/2118510

Hagan, J. (1993). The social embeddedness of crime and unemployment. Criminology, 31, 465-491. doi: 10. 1111/j.1745-9125.1993.tb01138.x.

Haney, C. (2003). The psychological impact of incarceration: Implications for post prison adjustment. In J. Travis \& M. Waul (Eds.), Prisoners once removed: The impact of incarceration and re-entry on children, families, and communities (pp. 33-66). Washington, DC: Urban Institute.

Hair, J. F., Anderson, R. E., Tatham, R. L. \& Black, B. C. (1998). Multivariate Data Analysis, The Prentice Hall International, Eaglewood Cliff, NJ.

Hair, J. F., Andersen, R. E. \& Tatham, R. L. (2010). Multivariate data analysis (7thed.). Upper Saddle River, NJ: Pearson Prentice Hall.

Hair, J. F., Ringle, C. M. \& Sarstedt, M. (2011). PLS-SEM: Indeed a silver bullet. The Journal of Marketing Theory and Practice, 19(2), 139-152.

Harding, D. (2003). Jean Valjean's dilemma: The management of ex-convict identity in the search for employment. Deviant Behaviour, 24, 571-595.

Harris, P. W., Lockwood, B. \& Mengers, L. (2009). ACJCA white Paper: Defining and Measuring Recidivism. http://www.cjca.net

Hirschfield, P. J. \& Piquero, A. R. (2010). Normalization and legitimation: Modelling stigmatizing attitudes toward ex-offenders. Criminology, 48(1), 27-55.

Holzer, H. J., Raphael, S. \& Stoll, M. A. (2002a). Can employers play a more positive role in prisoner re-entry? Washington, DC: Urban Institute.

Iguchi, M. Y., Bell, J., Ramchand, R. N. \& Fain, T. (2005). How criminal system racial disparities may translate into health disparities. Journal of health care for the poor and underserved, 16(4), 48-56.

Kershaw, C., Goodman, J. \& White, S. (1999). Reconvictions of Offenders Sentenced or Discharged from Prison in 1995, England and Wales. Statistical Bulletin 19/99. London: Home Office.

Kushel, M., Hahn, J., Evans, D., Bangsberg, D. \& Moss, A. (2005). Revolving doors: Imprisonment amongst the homeless and marginally housed population. American Journal of Public Health, 95, 1747-1752. doi: 10.2105/AJPH.2005.065094

Kling, J. (2006). Incarceration length, employment, and earnings. American Economic Review, 96, 863-876. doi:10.1257/aer.96.3.863

Krieger, N. (2012). Methods for the scientific study of discrimination and health: an eco social approach. American journal of public health, 102(5), 936-944.

Langan, P. \& Levin, D. (2002). Recidivism of Prisoners Released in 1994. Washington, DC: US Department of Justice, Bureau of Justice Statistics

La Vigne, N., Visher, C. \& Castro, J. (2004). Chicago prisoners' experiences returning home. Washington, DC: The Urban Institute.

LeBel, T. (2012). Invisible stripes? Formerly incarcerated persons' perceptions of stigma. Deviant Behavior, 33, 89-107. doi:10.1080/01639625.2010.538365.

Listwan, S. J., Piquero, N. L. \& Voorlis, P. V. (2010). Recidivism among a While-Collar Sampled: Does Personality matter? Australia \& New Zealand Journal of Criminology, 43, 156-174

Lloyd, C., Mair, G. \& Hough, M. (1994). Explaining Reconviction Rates: A Critical Analysis. Home Office Research Study No. 136. London: HMSO

Lyons, C. \& Petit, B. (2011). Compounded disadvantage: Race, incarceration and wage growth. Social Problems, 58, 257-280. doi:10.1525/sp.2011.58.2.257.

Mallik-Kane, K. \& Visher, C. (2008). Health and prisoner re-entry: How physical, mental and substance abuse conditions shade the process of reintegration. Washington, DC: The Urban Institute.

Maltz, M. D. (2001). Recidivism. Academic Press, Inc. Orlando, Florida.

Massoglia, M., Remster, B. \& King, R. D. (2011). Stigma or separation? Understanding the incarcerationdivorce relationship. Social Forces, 90, 133-155. doi:10.1093/sf/90.1.133.

Meade, B., Steiner, B., Makarious, M. \& Travis, L. (2012). Estimating a Dose- Response Relationship between Times Served in Prison and Recidivism. Journal of Research in Crime and Delinquency, 50(4), 525-550.

Naser, R. \& La Vigne, N. (2006). Family support in the prisoner re-entry process: Expectations and realities. Journal of Offender Rehabilitation, 43, 93-106. doi: 10.1300/J076v43n01_05 
Nelson, M., Dees, P. \& Allen, C. (1999). The first month out: Post incarceration experiences in New York City. Federal Sentencing Reporter, 24, 70-71. doi:10.1525/fsr.2011.24.1.72.

Nunnally, J. C. \& Bernstein, I. H. (1994). Psychometric Theory, 3rd ed., McGraw-Hill, New York.

O'Donnell, I., Baumer, E. P. \& Hughes, N. (2008). Recidivism in the Republic of Ireland. Criminology and Criminal Justice, 8(2), 123-146.

Ostermann, M. (2011). Recidivism and the propensity to forgo parole release. Justice Quarterly, 29, 596-618. doi:10.1080/07418825.2011.570362.

Pager, D. (2003). The mark of a criminal record. American Journal of Sociology, 108, 937-975.

Pager, D. (2007). Marked: Race, crime and finding work in an era of mass incarceration. Chicago: University of Chicago Press.

Pager, D. \& Shepherd, H. (2008). The sociology of discrimination: racial discrimination in employment, housing, credit, and consumer markets. Annual Review of Sociology, 34, 181-209.

Pager, D., Western, B. \& Bonikowski, B. (2009a). Discrimination in a low-wage labour market: a field experiment. American Sociological Review, 74(5), 777-799.

Pallant, J. (2001). SPSS survival manual: A step by step guide to data analysis using SPSS for windows (3rd ed.). England: McGraw Hill open University Press.

Richards, S. \& Jones, R. (2004). Beating the perpetual incarceration machine: Overcoming structural impediments to re-entry. In S. Maruna \& R. Immarigeon (Eds.), After crime and punishment: Pathways to offender reintegration (pp. 201-232). Collompton, England: Willan Publishing.

Schmallenger, F. A. \& Smykla, J. 0. (2005). Corrections in the 21st Century. Boston: McGraw Hill

Schnittker, J. \& John, A. (2007). Enduring stigma: the long-term effects of incarceration on health. Journal of Health and Social Behavior, 48(2), 115-130.

Smedley, B. D., Stith, A. Y. \& Nelson, A. R. (2003). In N. A. Press (Ed.), Unequal Treatment: Confronting Racial and Ethnic Disparities in Health Care. Washington, D.C: Institute of Medicine.

Stahler, G. J., Mennis, J., Belenko, S., Welsh, W. N., Hiller, M. L. \& Zajace, G. (2013). Predicting recidivism for Released State Prison Offenders: Examining the Influence of individuals and Neighbourhood Characteristics and Spatial contagion on the likelihood of Reincarceration. Criminal Justice and Behaviour, 40(6), 690-711.

Stone, M. (1974). Cross-validatory choice and assessment of statistical predictions. Journal of the Royal Statistical Society. Series B (Methodological), 111-147

Sykes, G. M. (2007). The society of captives: A study of a maximum security prison. Princeton, NJ: Princeton University Press. (Original published 1958).

Turney, K., Lee, H. \& Comfort, M. (2013). Discrimination and psychological distress among recently released male prisoners. American journal of men's health, 1557988313484056.

Travis, J. \& Petersilia, J. (2001). Re-entry reconsidered: A new look at an old question. Crime and Delinquency, 47, 291-313. doi:10.1177/0011128701047003001.

Travis, L. \& Stacey, J. (2010). A half century of parole rules: Conditions of parole in the United States, 2008. Journal of Criminal Justice, 38, 604-608.

Travis, J., Solomon A. L. \& Waul, M. (2001). From Prison to Home: The Dimensions and Consequences of Prisoner Re-entry. Washington, DC: Urban Institute Press.

Uggen, C. (2000). Work as a turning point in the life course of criminals: A duration model of age, employment, and recidivism. American Sociological Review, 65(4), 529-546.

Uggen, C. \& Manza, J. (2002). Democratic contraction? Political consequences of felon disenfranchisement in the United States.

Uggen, C. Manza, J. \& Behrens, A. (2004). Less than the Average Citizen: Stigma, Role Transition, and the Civic Reintegration of Convicted Felons. Cullompton, England: Willan Publishing.

Uggen, C., Vuolo, M., Lageson, S., Ruhland, E. \& Whitham, H. K. (2014). The Edge of Stigma: An Experimental Audit of the Effects of Low-Level Criminal Records on Employment. Criminology, 52(4), 627-654.

Visher, C., Debus-Sherrill, S. \& Yahner, J. (2008). Employment after prison: A longitudinal study of former prisoners. Justice Quarterly, 28, 698-718. doi: 10.1080/07418825.2010.535553

Visher, C. \& Kachnowski, V. (2007). Finding work on the outside: Results from returning home project in Chicago. In S. Bushway, M. Stoll, \& D. Weiman (Eds.), Barriers to re-entry: The labor market for returned prisons in post-industrial America (pp. 80-113). New York, NY: Russell Sage.

Visher, C., Debus-Sherrill, S. \& Yahner, J. (2008). Employment after prison: A longitudinal study of former prisoners. Justice Quarterly, 28, 698-718.doi10.1080/07418825.2010.535553 
Waldfogel, J. (1994). Does conviction have a persistent effect on income and employment? International Review of Law and Economics, 14, 103-119.

Wartna, B. S. J. \& Nijssen, L. T. J. (2006). National Studies on Recidivism: An Inventory of Large-Scale Recidivism Research in 33 European Countries. The Hague: WODC.

Western, B. (2006). Punishment and inequality in America. New York, NY: Russell Sage Foundation.

Western, B., Kling, J. \& Weiman, D. (2001). The labor consequences of incarceration. Crime and Delinquency, 47, 410-427. doi:10.1177/0011128701047003007.

Williams, D. R. (1999). Race, socioeconomic status, and health the added effects of racism and discrimination. Annals of the New York Academy of Sciences, 896(1), 173-188.

Williams, D. R. \& Mohammed, S. A. (2009). Discrimination and racial disparities in health: evidence and needed research. Journal of behavioural medicine, 32(1), 20-47. 